\title{
Preanalytical phase - a continuous challenge for laboratory professionals
}

\author{
Ana-Maria Simundic ${ }^{*}$, Giuseppe Lippi² \\ ${ }^{1}$ Editor-in-chief, Biochemia Medica, Zagreb, Croatia; EFLM (formerly EFCC) Working-group on Preanalytical Phase, chair \\ ${ }^{2}$ Clinical Chemistry and Hematology Laboratory, Academic Hospital of Parma, Parma, Italy; Editorial Board member; EFLM (formerly \\ EFCC) Working-group on Preanalytical Phase, member
}

*Corresponding author: am.simundic@gmail.com

\begin{abstract}
Preanalytical phase is the most vulnerable part of the total testing process and is considered to be among the greatest challenges to the laboratory professionals. However, preanalytical activities, management of unsuitable specimens and reporting policies are not fully standardized, nor harmonized worldwide. Several standards related to blood sampling and sample transportation and handling are available, but compliance to those guidelines is low, especially outside the laboratory and if blood sampling is done without the direct supervision of the laboratory staff. Furthermore, for some most critical procedures within the preanalytical phase, internationally accepted guidelines and recommendations as well as related quality measures are unfortunately unavailable. There is large heterogeneity in the criteria for sample rejection, the different strategies by which unacceptable samples are managed, processed and test results reported worldwide. Management of unacceptable specimens warrants therefore immediate harmonization. Alongside the challenging and long road of patient safety, preanalytical phase offers room for improvement, and Editors at Biochemia Medica Journal definitely hope to continue providing a respective mean for reporting studies on different preanalytical phase topics. With pleasure and delight we invite potential future authors to submit their articles examining the quality of various preanalytical activities to Biochemia Medica. We will keep nurturing this topic as our prominent feature and by this we hope to be able to deliver valid evidence for some future guidelines and recommendations.
\end{abstract}

Key words: preanalytical phase; errors; quality indicators; phlebotomy; blood sampling

Accepted: May 10, 2012

\section{Introduction}

Preanalytical phase is nowadays recognized as the most vulnerable part of the total testing process. Due to their impact on the quality of results of laboratory testing, preanalytical errors have been included within the greatest challenges to the laboratory professionals, during the last 20 years $(1,2)$. Unfortunately, preanalytical activities, management of unsuitable specimens and reporting policies are not fully standardized, nor harmonized worldwide.

\section{Blood sampling procedures}

The Clinical Laboratory Standards Institute (CLSI) has issued several standards related to blood sampling and sample transportation and handling (3-5). The compliance to those guidelines is low, however, especially in cases when blood is collected outside the laboratory and without the direct supervision of the laboratory staff (6-9). Moreover, some recommendations have recently been challenged, such as recommendation for patient identification procedure $(10,11)$ and sample mixing (12). Therefore, to achieve appropriate quality improvement and to reduce the burden of preventable errors, standardization of the preanalytical procedures including patient preparation and identification, sample collection, transport, handling, storage and preparation for testing should become our major focus. Standardization of several preanalytical activities can be indeed achieved by major adherence to available guidelines, implementation of total quality management system that include preanalytical requirements, as well as con- 
tinuous education of the health staff with blood sampling responsibilities $(13,14)$.

\section{Management of unsuitable specimens}

For some most critical procedures within the preanalytical phase, internationally accepted guidelines and recommendations are unfortunately unavailable, as are unavailable the related quality measures (15). Although some national societies have issued their national guidelines to standardize some preanalytical issues (16), there are still no universally accepted guidelines for management of unacceptable specimens. This is even more alarming if one considers the large heterogeneity in the criteria for sample rejection, the different strategies by which unacceptable samples are managed, processed and test results reported worldwide. Management of unacceptable specimens warrants therefore immediate harmonization.

The major obstacle to achieve an efficient uniformity of practices lays in the lack of universal consensus due to the numerous conflicting reports, great heterogeneity in the study design and the lack of high quality evidence based studies, which could provide valid and unbiased evidence for the effect of some preanalytical error on the laboratory test result.

Heterogeneity in the study design is due to many reasons. First, different authors have used different sampling systems, different tube types and additives and on different analytical platforms. Also, different strategies have been used to produce and study interferences such as lipemia, hemolysis and icterus (17). Different cut-off values for serum indices are used to test for interferences and different thresholds are also applied to verify the observed biases. For all the above mentioned reasons, study results are usually scarcely reproducible.

\section{Preanalytical phase studies recently published in Biochemia Medica}

Editors at Biochemia Medica are especially proud of the increasing number of studies in this field, recently submitted and accepted for publication in our Journal. This proves that authors have recognized our Journal as an appropriate channel for reporting studies on preanalytical phase to the wide audience of laboratory professionals. Below is the overview of some most convincing studies published in the Journal during the last couple of years.

Lippi and his co-workers have described specific software developed for the recording preanalytical errors in their laboratory. With this study, the authors have showed that the implementation of this very simple and absolutely free software for systematical recording of preanalytical errors is highly favorable, since it enables harmonization of incident reporting practices within the same laboratory and even across national and international laboratories (18). This is particularly noteworthy since incidents are commonly underreported in the preanalytical phase (19).

It has long been known that venous stasis due to prolonged tourniquet application may alter the concentration and activity of several analytes in blood $(20,21)$. Recently, transillumination devices have been proposed as reliable and simple tool for eliminating the venous stasis during phlebotomy. The efficiency of this system in limiting the effect of venous stasis has been studied by Lima-Oliveira et al. for coagulation testing (22), routine hematological testing (23) and for clinical biochemistry testing in this Journal (24).

Patient preparation, body position, health status, physical activity have long been recognized as major determinants of variations of many laboratory parameters. In this Journal, we have also published some very interesting observations on the effect of winter swimming and exercise on selected laboratory parameters $(25,26)$.

Lipemia is a common preanalytical problem, causing significant interferences in the results of laboratory testing. Calmarza et al. have studied the effect of hypertriglyceridaemia on several biochemistry analytes and have observed that lipemia is associated with clinically significant interferences for phosphorus, creatinine, total protein and calcium measurement. Even more interestingly, the authors have also reported that those interferences 
might be effectively attenuated or completely removed by ultracentrifugation of the sample (27).

Several centrifugation protocols as a reliable strategy for removing lipemia have been investigated by Dimeski et al. (28). In their study, Dimeski et al. have evaluated a procedure of high speed centrifugation using the micro-centrifuge compared with an ultracentrifuge in their ability to reduce the interference of lipids in lipemic sera pools. According to their evidence, high speed micro-centrifugation would provide a suitable, more practical and less expensive alternative to ultracentrifugation for analyses of sodium, creatinine, urate, total protein, lactate dehydrogenase (LD), magnesium and, cholesterol and triglyceride if measured on a Beckman DxC800 analyser (Beckman Coulter, Fullerton, CA, USA). This observation merits special attention, since the ultracentrifuge is nowadays only available in highly specialized laboratories.

Hemolysis is the most common preanalytical interference and still one of the biggest challenges to the laboratory specialists (29). Koseoglu et al. have carried out a study to investigate the effects of the different degree of hemolysis for some most commonly used biochemical parameters (30). This paper is of utmost importance since it provides clear evidence for the clinically significant differences caused by visually undetectable (plasma hemoglobin $<0.5 \mathrm{~g} / \mathrm{L}$ ) to moderate hemolysis for $\mathrm{LD}$ and aspartate aminotransferase (AST), potassium and total bilirubin, whereas biases for some other parameters were found to be statistically significant, but remained within the conventional Clinical Laboratory Improvement Amendments (CLIA) limits (albumin, alkaline phosphatase (ALP), amylase, chloride, HDL-cholesterol, creatine kinase (CK), glucose, magnesium, total protein, triglycerides, unsaturated iron binding capacity (UIBC) and uric acid). The article by Koseoglu et al. is currently the third most frequently downloaded paper from the Biochemia Medica web site in the period from January - June 2012, with over 4000 downloads. This clearly shows high degree of interest and concern for hemolysis by laboratory professionals.

In another study by Lippi and his coworkers, which should hence be considered the continuation of the above mentioned study by Koseoglu et al. it has been reliably shown that corrective formulas meant to adjust the results of several laboratory parameters for the hemolysis degree are unreliable and potentially misleading, since mechanical injury of blood components and subsequent release of cell blood components into the serum or plasma does not occur homogeneously (31).

\section{Preanalytical phase studies published in this issue of Biochemia Medica}

In this issue of Biochemia Medica we publish several articles dealing with other preanalytical phase. Lima-Oliveira and his colleagues report an interesting comprehensive validation study of different serum vacuum tubes for routine clinical chemistry laboratory testing (32). This study is important due to the fact that some blood collection tube components such as various additives, clot activators, anticoagulants, surfactants, lubricants, stoppers and separator gels may interact with blood and therefore cause variable biases of the results of different laboratory tests (33). Unfortunately, collection devices are often not validated prior to their routine use and their effect is often neglected.

Another interesting article published in this issue of Biochemia Medica is the extensive analysis on the effect of different syringe volume, needle size and sample volume on blood gas analysis in syringes washed with heparin, performed by Küme et al. (34). In this work, the authors have shown that sample dilution and heparin final concentration in the sample, due to the nonstandardized sampling, in syringes washed with liquid heparin, gives rise to clinically significant biases for pCO2 and electrolytes.

The last article dedicated to the preanalytical phase issues is that of Cuhadar et al. (35). In their study the authors have assessed the stability of some most common biochemical parameters in serum separator tubes with or without gel barrier subjected to various storage conditions. Their observations may thus serve as the basis for determining the appropriate time and storage conditions for re-testing those biochemical parameters in everyday routine activity. 


\section{An invitation to submit manuscripts dealing with preanalytical phase to Biochemia Medica}

Alongside the challenging and long road of patient safety, there is wiggle room for tackling the route for improvement, and we definitely hope to continue providing a respective mean for reporting studies on different preanalytical phase topics in this Journal. With pleasure and delight we invite potential future authors to submit their articles examining the quality of various preanalytical activi-

\section{References}

1. Lippi G, Chance JJ, Church S, Dazzi P, Fontana R, Giavarina $D$, et al. Preanalytical quality improvement: from dream to reality. Clin Chem Lab Med 2011;49:1113-26.

2. Lippi G, Simundic AM. Total quality in laboratory diagnostics. It's time to think outside the box. Biochem Med 2010;20:5-8.

3. Clinical Laboratory Standards Institute. Procedures for the Handling and Processing of Blood Specimens for Common Laboratory Tests; Approved Guideline - Fourth Edition. CLSI document H18-A4. Wayne, PA: Clinical and Laboratory Standards Institute; 2010.

4. Clinical Laboratory Standards Institute. Procedures for Collection of Diagnostic Blood Specimens by Venipuncture; Approved Guideline - Sixth Edition. CLSI document H3A6. Wayne, PA: Clinical and Laboratory Standards Institute; 2007.

5. Clinical Laboratory Standards Institute. Collection, transport, and processing ot blood specimens for testing plasma-based coagulation assays: Approved Guideline - Sixth Edition. CLSI document H21-A5. Wayne, PA: Clinical and Laboratory Standards Institute; 2008.

6. Bilic-Zulle L, Simundic AM, Supak Smolcic V, Nikolac N, Honovic $L$. Self reported routines and procedures for the extraanalytical phase of laboratory practice in Croatia - crosssectional survey study. Biochem Med 2010;20:64-74.

7. Simundic AM, Bilic-Zulle L, Nikolac N, Supak-Smolcic V, Honovic $L$, Avram $S$, et al. The quality of the extra-analytical phase of laboratory practice in some developing European countries and Mexico - a multicentric study. Clin Chem Lab Med 2011;49:215-28.

8. Söderberg J, Brulin C, Grankvist K, Wallin O. Preanalytical errors in primary healthcare: a questionnaire study of information search procedures, test request management and test tube labelling. Clin Chem Lab Med 2009;47:195-201.

9. Wallin $O$, Söderberg J, Van Guelpen B, Stenlund H, Grankvist K, Brulin C. Blood sample collection and patient identification demand improvement: a questionnaire study of preanalytical practices in hospital wards and laboratories. Scand J Caring Sci 2010;24:581-91. ties to Biochemia Medica. We will keep nurturing this topic as our prominent feature and by this we hope to be able to deliver valid evidence for some future guidelines and recommendations hopefully under the auspices of accredited international bodies such as the European Federation of Clinical Chemistry and Laboratory Medicine (EFLM).

In this respect, we also invite you all to the forthcoming 2nd EFLM-BD European Conference on Preanalytical Phase that will be held in the wonderful city of Zagreb, 1-2 March 2013.

10. Hawkins RC. Specimen labeling: before or after collection? Clin Chem Lab Med 2011, in press, DOI: 10.1515/ cclm.2011.737.

11. Lippi G, Sonntag O, Plebani M. Appropriate labeling of blood collection tubes: a step ahead towards patient's safety. Clin Chem Lab Med 2011, in press, Doi 10.1515/ CCLM.2011.736.

12. Lippi G, Plebani M. Primary blood tubes mixing: time for updated recommendations. Clin Chem Lab Med 2012;50:599600.

13. Lippi G, Salvagno GL, Montagnana M, Franchini M, Guidi GC. Phlebotomy issues and quality improvement in results of laboratory testing. Clin Lab 2006;52:217-30.

14. Lippi G, Salvagno GL, Montagnana M, Guidi GC. The skilled phlebotomist. Arch Pathol Lab Med 2006;130:1260-1.

15. Plebani M, Sciacovelli L, Lippi G. Quality indicators for laboratory diagnostics: consensus is needed. Ann Clin Biochem 2011;48:479.

16. Lippi G, Banfi G, Buttarello M, Ceriotti F, Daves $M$, Dolci $A$, et al. Recommendations for detection and management of unsuitable samples in clinical laboratories. Clin Chem Lab Med 2007;45:728-36.

17. Lippi G. Interference Studies: Focus on Blood Cell Lysates Preparation and Testing. Clin Lab 2012;58:351-5.

18. Lippi G, Bonelli P, Rossi R, Bardi M, Aloe R, Caleffi A, et al. Development of a preanalytical errors recording software. Biochem Med 2010;20:90-5.

19. Söderberg J, Grankvist K, Brulin C, Wallin O. Incident reporting practices in the preanalytical phase: Low reported frequencies in the primary health care setting. Scand J Clin Lab Invest 2009;69:731-5.

20. Lippi G, Salvagno GL, Montagnana M, Brocco G, Guidi GC. Influence of short-term venous stasis on clinical chemistry. Clin Chem Lab Med 2005;43:869-75.

21. Cengiz M, Ulker P, Meiselman HJ, Baskurt OK. Influence of tourniquet application on venous blood sampling for serum chemistry, hematological parameters, leukocyte activation and erythrocyte mechanical properties. Clin Chem Lab Med 2009;47:769-76. 
22. Lima-Oliveira G, Salvagno GL, Lippi G, Montagnana $M$, Scartezini M, Picheth G, Guidi GC. Elimination of the venous stasis error for routine coagulation testing by transillumination. Clin Chim Acta 2011;412:1482-4.

23. Lima-Oliveira G, Lippi G, Salvagno GL, Montagnana M, Scartezini M, Guidi GC, Picheth G. Transillumination: a new tool to eliminate the impact of venous stasis during the procedure for the collection of diagnostic blood specimens for routine haematological testing. Int J Lab Hematol 2011;33:457-62.

24. Lima-Oliveira G, Lippi G, Salvagno GL, Montagnana M, Pitanguiera Manguera $C L$, Sumita NM, et al. New ways to deal with known preanalytical issues: use of transilluminator instead of tourniquet for easing vein access and eliminating stasis on clinical biochemistry. Biochem Med 2011;21:152-9.

25. Lombardi G, Ricci C, Banfi G. Effects of winter swimming on haematological parameters. Biochem Med 2011;21:71-78.

26. Lippi G, Cervellin G, Banfi G, Plebani M. Cardiac troponins and physical exercise. It's time to make a point. Biochem Med 2011;21:55-64.

27. Calmarza P, Cordero J. Lipemia interferences in routine clinical biochemical tests. Biochem Med 2011;21:160-6.

28. Dimeski G, Jones BW. Lipaemic samples: Effective process for lipid reduction using high speed centrifugation compared with ultracentrifugation. Biochem Med 2011;21:86-94.
29. Simundic AM, Topic E, Nikolac N, Lippi G. Hemolysis detection and management of hemolysed specimens. Biochem Med 2010;20:154-9.

30. Koseoglu M, Hur A, Atay A, Cuhadar S. Effects of hemolysis interference on routine biochemistry parameters. Biochem Med 2011;21:79-85.

31. Lippi G, Avanzini P, da Pavesi F, Bardi M, Ippolito L, Aloe R, et al. Studies on in vitro hemolysis and utility of corrective formulas for reporting results on hemolyzed specimens. Biochem Med 2011;21:297-305.

32. Lima-Oliveira G, Lippi G, Salvagno GL, Montagnana M, Picheth G, Guidi GC. Pre analytical management: serum vacuum tubes validation for routine clinical chemistry. Biochem Med 2012;22:180-6.

33. Bowen RA, Hortin GL, Csako G, Otanez OH, Remaley AT. Impact of blood collection devices on clinical chemistry assays. Clin Biochem 2010;43:4-25.

34. Kume T, Sisman AR, Solak A, Tuglu B, Cinkooglu B, Coker $C$. The effects of different syringe volume, needle size and sample volume on blood gas analysis in syringes washed with heparin. Biochem Med 2012;22:189-201.

35. Cuhadar S, Atay A, Koseoglu M, Dirican A, Hur A. Stability studies of common biochemical analytes in serum separator tubes with or without gel barrier subjected to various storage conditions. Biochem Med 2012;22:202-14.

\section{Predanalitička faza - neprekidni izazov za laboratorijske stručnjake}

\section{Sažetak}

Od svih laboratorijskih postupaka, u predanalitičkoj fazi je vjerojatnost za pogrešku najveća i stoga ona predstavlja trajni izazov u laboratorijskoj medicini. No, predanalitička faza laboratorijskog rada, upravljanje neprihvatljivim uzorcima i način izvještavanja nisu u potpunosti standardizirani, niti harmonizirani na međunarodnoj razini. Postoje standardi za uzorkovanje te za transport i rukovanje uzorcima, no poznato je da se osoblje ne pridržava tih smjernica, pogotovo ako se uzorkovanje obavlja izvan laboratorija i izvan neposrednog nadzora laboratorijskih stručnjaka. Štoviše, za neke najspornije postupke predanalitičke faze, još uvijek ne postoje međunarodno prihvaćene smjernice i standardi kvalitete. Među laboratorijima postoje velike razlike u kriterijima prihvatljivosti uzoraka, politikom upravljanja neprihvatljivim uzorcima i izdavanju rezultata iz istih. Iz tog je razloga upravljanje neprihvatljivim uzorcima nužno što prije harmonizirati. Na dugom putu prema sigurnosti bolesnika, kao konačnom cilju, mnogi su izazovi. Predanalitička faza u tom smislu svakako nudi prostor za poboljšanje, a mi, urednici časopisa Biochemia Medica se nadamo da ćemo i dalje biti časopis izbora za objavljivanje radova s područja predanalitičke faze. S osobitim zadovoljstvom pozivamo ovim putem sve potencijalne buduće autore da šalju svoje radove s područja predanalitičke faze u časopis Biochemia Medica. Mi ćemo nastaviti njegovati tu temu kao naše istaknuto obilježje u nadi da će radovi objavljeni u našem časopisu poslužiti kao vrijedna građa za neke buduće smjernice i preporuke.

Ključne riječi: predanalitička faza; pogreške; indikatori kvalitete; vađenje krvi; uzorkovanje 